\title{
Water level and volume estimations of the Albano and Nemi lakes (central Italy)
}

\author{
Federica Riguzzi $\left({ }^{1}\right)\left({ }^{2}\right)$, Grazia Pietrantonio $\left({ }^{1}\right)$, Valerio Baiocchi $\left(^{(}\right)$and Augusto Mazzoni $\left({ }^{3}\right)$ \\ (1) Istituto Nazionale di Geofisica e Vulcanologia, Sezione CNT, Roma, Italy \\ (2) Dipartimento di Scienze della Terra, Università degli Studi «La Sapienza», Roma, Italy \\ $\left(^{3}\right)$ Università degli Studi «La Sapienza», Area di Geodesia e Geomatica, Roma, Italy
}

\begin{abstract}
In April 2006 an airborne laser scanning (LIDAR) survey of the Albano and Nemi craters was carried out to obtain a high resolution digital terrain model (DTM) of the area. We have integrated the LIDAR survey of the craters and the recent bathymetry of the Albano lake to achieve a complete DTM, useful for morphological studies. In addition, with a GPS RTK survey (July 2007) we estimated the Albano and Nemi mean lake levels respectively at $288.16 \mathrm{~m}$ and $319.02 \mathrm{~m}$ (asl). Based on the integrated DTM and the newly estimated water level values, we evaluated about 21.7.106 $\mathrm{m}^{3}$ the water volume loss of the Albano lake from 1993 to 2007, with an average rate of about $1.6 \cdot 10^{6} \mathrm{~m}^{3} / \mathrm{yr}$.
\end{abstract}

Key words Albano lake - Nemi lake - Colli Albani - DTM - airborne laser survey - bathymetric survey - GPS RTK

\section{Introduction}

The Albano and Nemi lakes partly fill two craters of the Colli Albani volcanic complex located in central Italy, about $15 \mathrm{~km} \mathrm{SE}$ of Rome, fig. 1. The area belongs to the potassic and ultrapotassic Roman Magmatic Province, a northwest-trending chain of volcanoes that developed along the Tyrrhenian Sea margin of Italy during middle and late Pleistocene time (De Rita et al., 1988; Trigila, 1995). The volcanic history of the Colli Albani is dominated by recurrent eruptive histories starting about $561 \mathrm{ka}$ and ending with the most recent and voluminous activity of the Albano maar ( $<70 \mathrm{ka})$ phase, that

Mailing address: Dr. Federica Riguzzi, Istituto Nazionale di Geofisica e Vulcanologia, Sezione CNT, Via di Vigna Murata 605, 00143 Roma, Italy; e-mail: riguzzi@ingv.it cannot be considered completely extinguished (Freda et al., 2006; Funiciello et al., 2003). In fact, this area is characterized by recurrent seismic activity (Feuillet et al., 2004; Amato et al., 1994; Tertulliani and Riguzzi, 1995; Riguzzi and Tertulliani, 1988; Molin, 1981); temperature and water composition variations (Boni et al., 1995; Calcara et al., 1995); gas emissions, $\mathrm{CO}_{2}$ and in minor part $\mathrm{H}_{2} \mathrm{~S}$ (Carapezza and Tarchini, 2007; Tuccimei et al., 2006; Carapezza et al., 2005; Carapezza et al., 2003; Pizzino et al., 2002; Chiodini and Frondini, 2001 and reference therein) and by significant ground deformations (Amato and Chiarabba, 1995; Anzidei et al., 1998; Salvi et al., 2004).

The Albano and Nemi lakes partially occupy the craters formed during the more recent volcanic activity. Their present water level is well below the drain tunnels built in each lake during the Roman age (398-397 BC) to regulate the level variations and for agriculture irrigations. These artificial pipes today do not drain any water as they are located some meters above the lake levels, thus testifying in someway the water volume reduction occurred in recent times. 


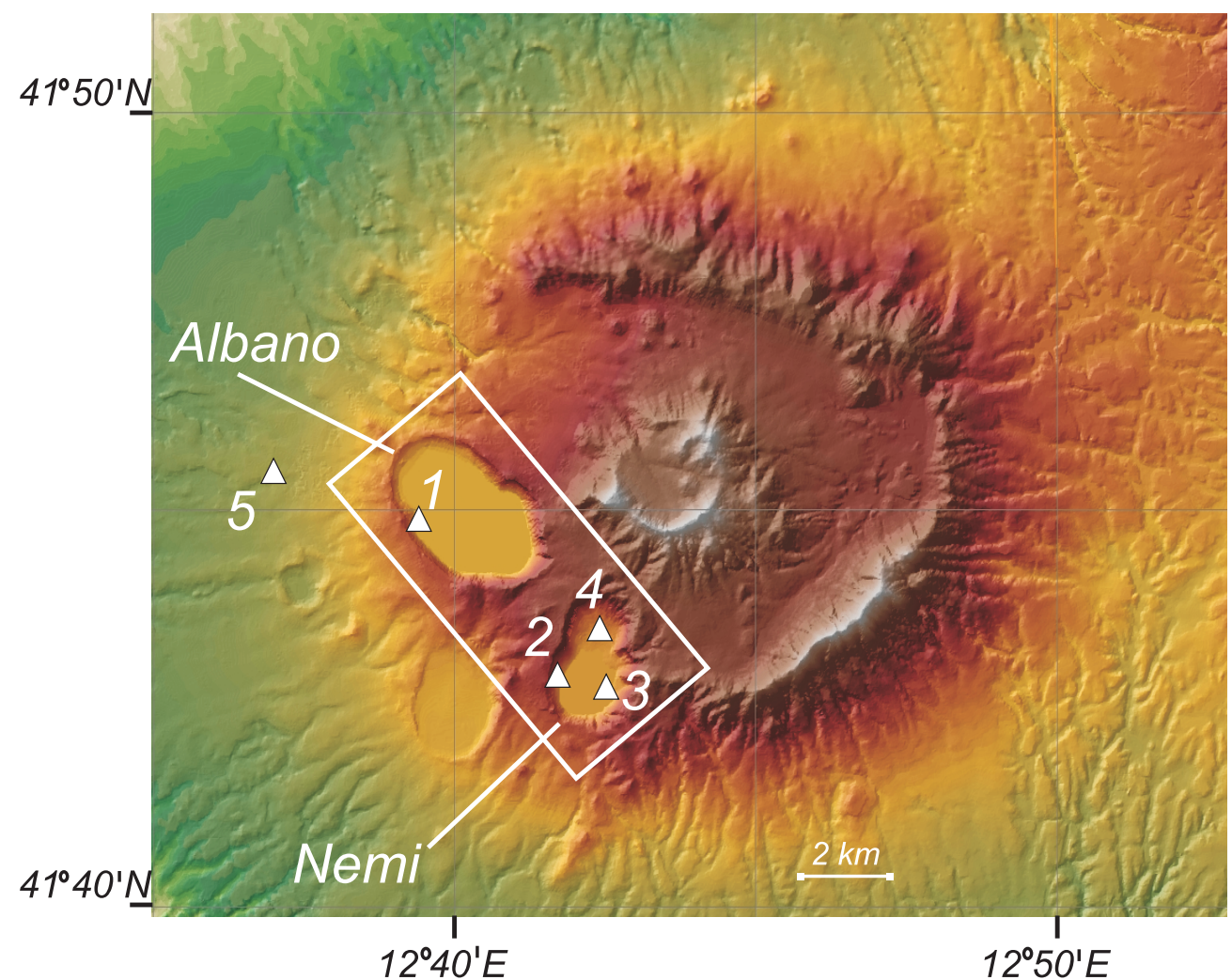

Fig. 1. The Colli Albani area, the white square indicates the area of the LIDAR survey. Numbers refer to sites reported in table II.

Recent papers (Funiciello et al., 2002; Funiciello et al., 2003; Anzidei et al., 2008) highlight the relevance of the detected high water level variations and catastrophic withdrawal of the Albano maar lake since pre-historic age as possible indicators of a sudden variation of $\mathrm{CO}_{2}$ flow and upwelling of hydrothermal fluids. Many studies involving different research fields have been carried out about the level variations of the Albano lake (Capelli and Mazza, 2005; Capelli et al., 2000; Dragoni, 1998; Boni et al., 1995). In the past, until the $4^{\text {th }}$ century B.C., catastrophic exudations occurred. The repetition of these events was prevented by the drain-tunnel dug by the Romans to control the water level, used until recent times.

The Nemi lake incurred another important human action, its water level was further lowered of about $23 \mathrm{~m}$ from 1928 to 1932, in order to facilitate the recovery of two large ancient Roman ships resting on the lake bottom thereafter, the water level was slowly left to increase again, remaining nowadays well below the drain tunnel level.

From 2005 to 2007 the Department of Civil Protection financed the project DPC115 V3_1, the first one specifically oriented to the definition of potential hazards and crisis levels of the Colli Albani. Considering gas emissions, seismic swarms and ground deformation the most compelling unrest activities of the volcano, one of the priorities of the project was to study the dynamics of the area and their interferences with human activities, including local- 
scale ground deformation, stress field, slope stability, recent eruptive processes, crater lake evolution, quaternary mass flows.

In this framework, we assessed a detailed digital database to represent the morphology of the Albano and Nemi craters (fig. 1). The knowledge of the crater shapes (from LIDAR and bathymetry) and lake levels (from GPS RTK survey) makes it possible to infer the recent water volume loss of the Albano lake and the present water level of the Albano and Nemi lakes, rather different from the topographic values reported on the current Istituto Geografico Militare (IGM) tables.

\section{Bathymetry of the Albano lake}

In November 2005 a high precision bathymetric survey of the Albano maar lake was carried out. The bathymetric survey is well described in detail in Anzidei et al. (2006). Briefly, we want to recall here that to survey the submerged part of the Albano crater, due to the lake depth, two different multibeam sonars were used: the ultra high resolution Reson Seabat $8125\left(250\right.$ beams, swath $0.5^{\circ} \times 1.0^{\circ}, 455$ $\mathrm{Khz})$ up to $80 \mathrm{~m}$ depth and the Reson Seabat 8101 (101 beams, swath $1.5^{\circ} \times 1.5^{\circ}, 240 \mathrm{Khz}$ ) from $80 \mathrm{~m}$ to the bottom of the lake.

The positioning of the watercraft was defined by two GPS stations, the rover located on the mobile vehicle, working in RTK mode with differential corrections transmitted by a GSM modem and the reference GPS station (ALBA), located near the lake river, whose coordinates were estimated with centimeter accuracy with respect to the permanent station of INGR (Devoti et al., 2008), situated on the roof of the Istituto Nazionale di Geofisica e Vulcanologia, about $15 \mathrm{~km} \mathrm{NW}$ from the lake.

Due to the various ranges of depths and the consequent employ of two different kinds of sensors, the surveys allowed obtaining data at different resolution levels. The highest resolutions are achieved at shallow depths, within 80 $\mathrm{m}$, the lowest at the others. The mean deviations of the multibeam data show values ranging between $10-15 \mathrm{~cm}$ for depths within -20m; 15-30 $\mathrm{cm}$ between -20 and $-50 \mathrm{~m}$ and $30-50 \mathrm{~cm}$ at depths greater than $-50 \mathrm{~m}$ (Anzidei et al., 2006). To avoid the problem to manage irregular grids, due to the irregular resolutions, as first step the observations were interpolated on a regular grid with a mesh of $2 \mathrm{~m}$, calibrated on the resolution of the highest depths.

All the measured depths refer to the mean lake level, estimated at the moment of the survey at $336.7 \mathrm{~m}$ with respect to the WGS84 reference ellipsoid. The newly estimated maximum depth from bathymetry reaches $167.5 \mathrm{~m}$ and corresponds to distance between the mean lake level and the bottom of the central crater (Anzidei et al., 2006). The high resolution bathymetric survey allows the topographic shape and the morphology of the bottom and near the shore areas of the Albano crater to be defined in great detail (fig. 2, Anzidei et al., 2008; Mazzanti et al., 2007; Anzidei et al., 2006).

\section{Airborne laser scan survey of the Albano and Nemi craters}

The airborne laser scan (LIDAR) survey was carried out by the Compagnia Generale Ripreseaeree s.p.a. on 13 April 2006 to obtain a high resolution Digital Terrain Model of the Albano and Nemi craters. The flight covered an area of about $35 \mathrm{~km}^{2}$ including both the Albano and Nemi lakes and some surroundings (fig. 1, white rectangle).

The survey was carried out by an aircraft equipped with three main instrumental systems: a laser scanner device, a GPS devoted to the positioning of the aircraft and an inertial apparatus composed by three accelerometers and three gyroscopes to record the attitude variations of the aircraft during the flight.

The laser scanner device employed is the Optech ALTM 3033 system characterized by a highly focused laser beam modulated on a fixed infrared frequency. An oscillating mirror located in front of the laser is able to modify the direction of the ray pulses so that their sequence runs a defined trace on land. The mirror conducts the rays along a transversal direction with respect to the motion direction of the aircraft. The resulting scanning trajectory is given by the combination of the two motions and the on 


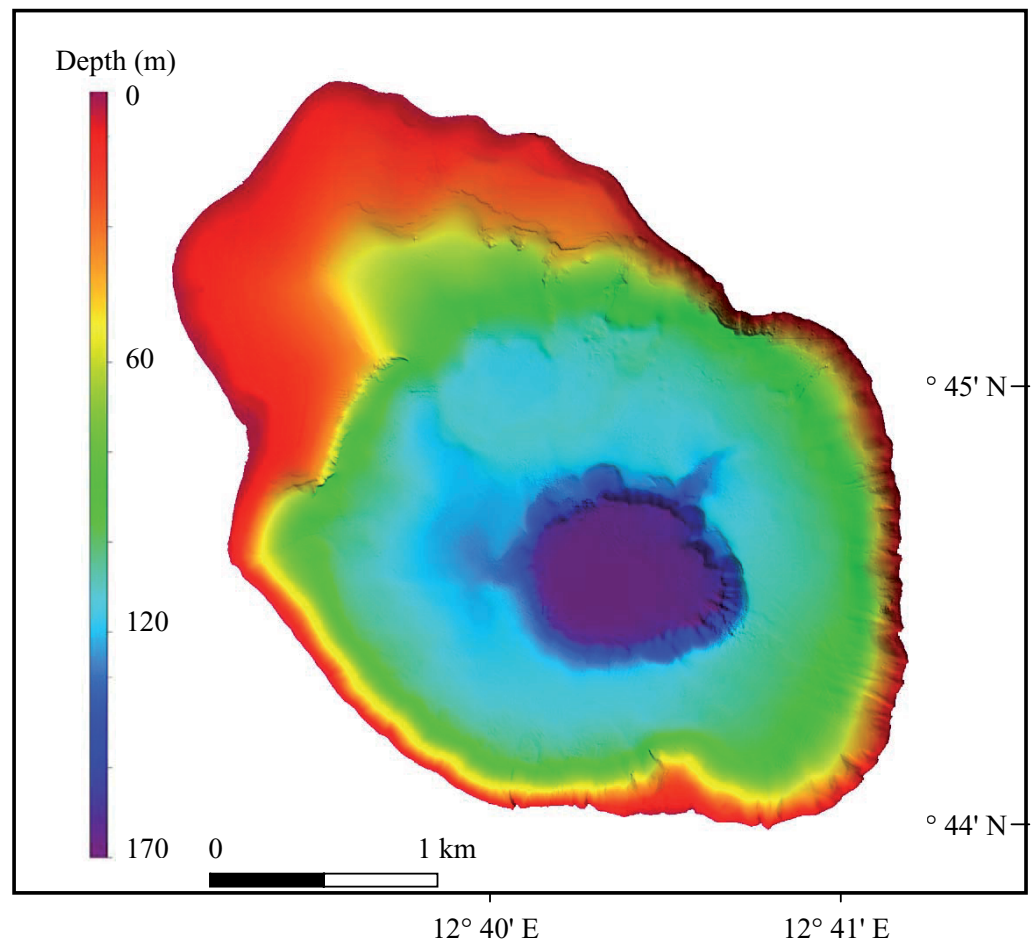

Fig. 2. The bathymetry of the Albano lake (modified after Anzidei et al., 2006).

land trace has the characteristic zigzag trend that allows a more uniform distribution of the surveyed points with respect to those obtained by sinusoidal traces.

The scanner records the intensity values of the backscattered signals, useful to discriminate in a relative way the kind of object lightened by the laser. The backscattered signal is recorded as a digital electric signal from the receiver and correlated with the GPS signal and inertial measurements synchronously recorded. The inertial system controls the aircraft attitude fluctuations during the flight, the GPS receiver provides the precise WGS84 positioning of the aircraft with respect to some on land control sites. The decorrelation of the backscattered pulse and the inertial correction and aircraft positioning estimate the coordinates of the surveyed points.

The survey was planned to cover the whole area by 13 stripes with an overlap of about $30 \%$ from a mean flight height of $1200 \mathrm{~m}$ with an expected nominal accuracy of about $\pm 15 \mathrm{~cm}$ (table I).

The area investigated by airborne laser scanning has highly variable morphology. In fact there are sectors of the craters characterized by steep slopes and other completely flat areas, most of them represented by the air-water interface (the lake surface area). Moreover some areas are highly vegetated and others are densely populated, making crucial the filtering procedure to separate the first from the last echoes to obtain a reliable representation of terrain. Consequently, the raw data were carefully filtered step by step. The first step consists of eliminating gross errors or anomalous sites simply recognizable being much higher or lower than the surrounding scattering points. The first may be produced by objects that do not rest on 
Table I. Airborne laser scan survey and data availability.

Survey features

- Flight height $1200 \mathrm{~m}$

- Mean density of points about 1 per m2

- Swath width $462.17 \mathrm{~m}$

- Scan angle \pm 11 degree

Products available

- Digital Terrain Model with mean accuracies

- Height within $50 \mathrm{~cm}$

- Planimetry within $1 \mathrm{~m}$

- Digital Surface Model (with vegetation and manufacts)

- DSM and DTM in Gauss-Boaga and WGS84 coordinates with orthometric and ellipsoidal heights

Unification with bathymetry

- DSM and DTM in Gauss-Boaga and WGS84 coordinates with orthometric and ellipsoidal heights

land, like flying birds or suspended electrical cables, whereas the second are due to multiple reflection effects. The elimination of this kind of outliers yelds a Digital Surface Model (DSM), i.e. the representation of terrain with vegetation and buildings. The second step consists of the vegetation filtering using the double echoes originating near the vegetation itself: in fact, as usual, a portion of the laser beam crosses the leaves and generates a second echo after the terrain reflection. This procedure is able to separate the two echoes if the vegetation heights are at least at metric level. The third step is the removal of artifacts and buildings by Terrascan $@$, analyzing the presence of strong gradients in the observations. This step is accomplished first automatically and then manually, to achieve a refined filtered file.

At the end of the whole processing procedure, the large amount of data (about $24 \cdot 10^{6}$ height values) does not permit the whole digital model to be managed in one file. Then, the surveyed area was divided into 17 plates corresponding to 17 different files. The DTM is available (request to riguzzi@ingv.it) in two forms: 1) as WGS84 heights of all the surveyed sparse points (ASCII format file, type .xyz) and 2) as heights interpolated on a regular grid (ASCII format file, type .asc) with mesh of 1x1 $\mathrm{m}$, both as ellipsoidal and orthometric heights.

It is almost impossible to assess the real accuracy of the LIDAR DTM, however it is possible to infer its quality level by comparing the heights obtained from different survey techniques; between the LIDAR and a kinematic GPS surveys we have differences within $50 \mathrm{~cm}$ (Pietrantonio et al., 2008); between the LIDAR and the GPS RTK surveys this value is reduced to $20 \mathrm{~cm}$ in flat areas (see table II). After the quality check, we unified the DTM obtained by the airborne laser survey and the bathymetry, cutting the area covered by the Albano lake (fig. 3). This step was carefully carried out by overlapping a georeferenced orthophoto of the Albano lake to the LIDAR DTM and eliminating all the heights located within the lake perimeter (corresponding to the unreliable values of the water heights from the LIDAR sur- 


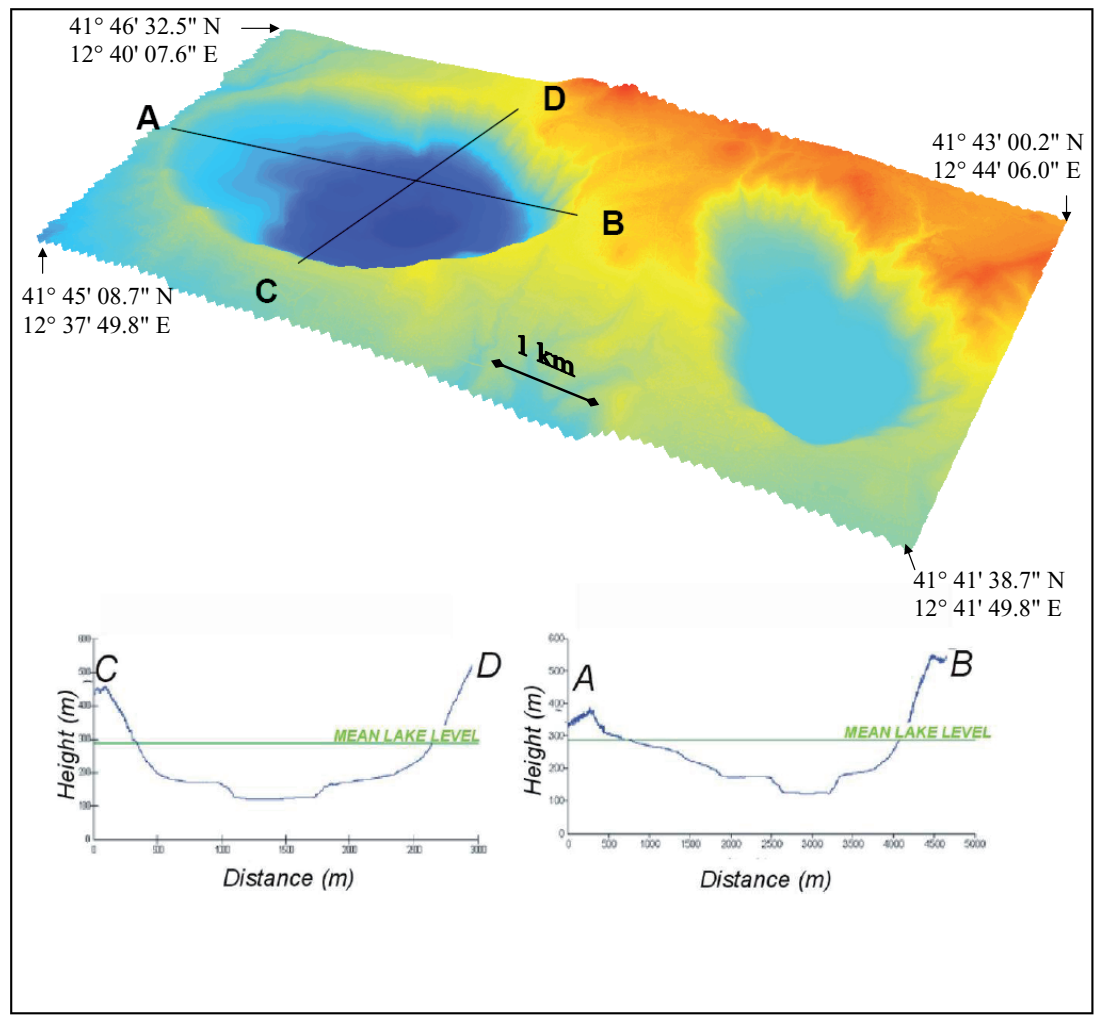

Fig. 3. DTM after the unification of bathymetry and LIDAR surveys.

vey). The error introduced with this procedure is within the mean accuracy level of the DTM. Then we unified the two cleaned, georeferenced height datasets by $\operatorname{Arcgis}^{\odot}$ having in origin different grids (laser $1 \mathrm{~m}$; bathymetry $2 \mathrm{~m}$ ); we chose to interpolate the $2 \mathrm{~m}$-gridded bathymetry to $1 \mathrm{~m}$ with the nearest neighbor algorithm, the most conservative procedure, to avoid discarding about half of the available LIDAR data.

\section{Water lake heights from Real Time Kinematic GPS survey (RTK)}

In July 2007, we carried out the RTK survey with two aims: the first, to measure the water level of the two lakes, since the LIDAR survey is not able to provide reliable data on water ta- bles; the second, to check if the GPS RTK heights were in agreement with those retrieved by the LIDAR survey and with a leveling benchmark located in the area.

The RTK technique estimates the position of the surveyed sites in real time with a precision comparable to the classic static GPS surveys. It is based on the capability of processing two data flows simultaneously: one coming from the receiver on site and the other coming from a network of GPS permanent stations with known coordinates. The height accuracy achievable by the RTK survey is at sub-decimetric level, sufficiently accurate for our aims, taking into account the lower accuracy of the LIDAR survey and the geoidal undulation model, known with decimetric accuracy.

The GPS RTK survey was carried out on 5 

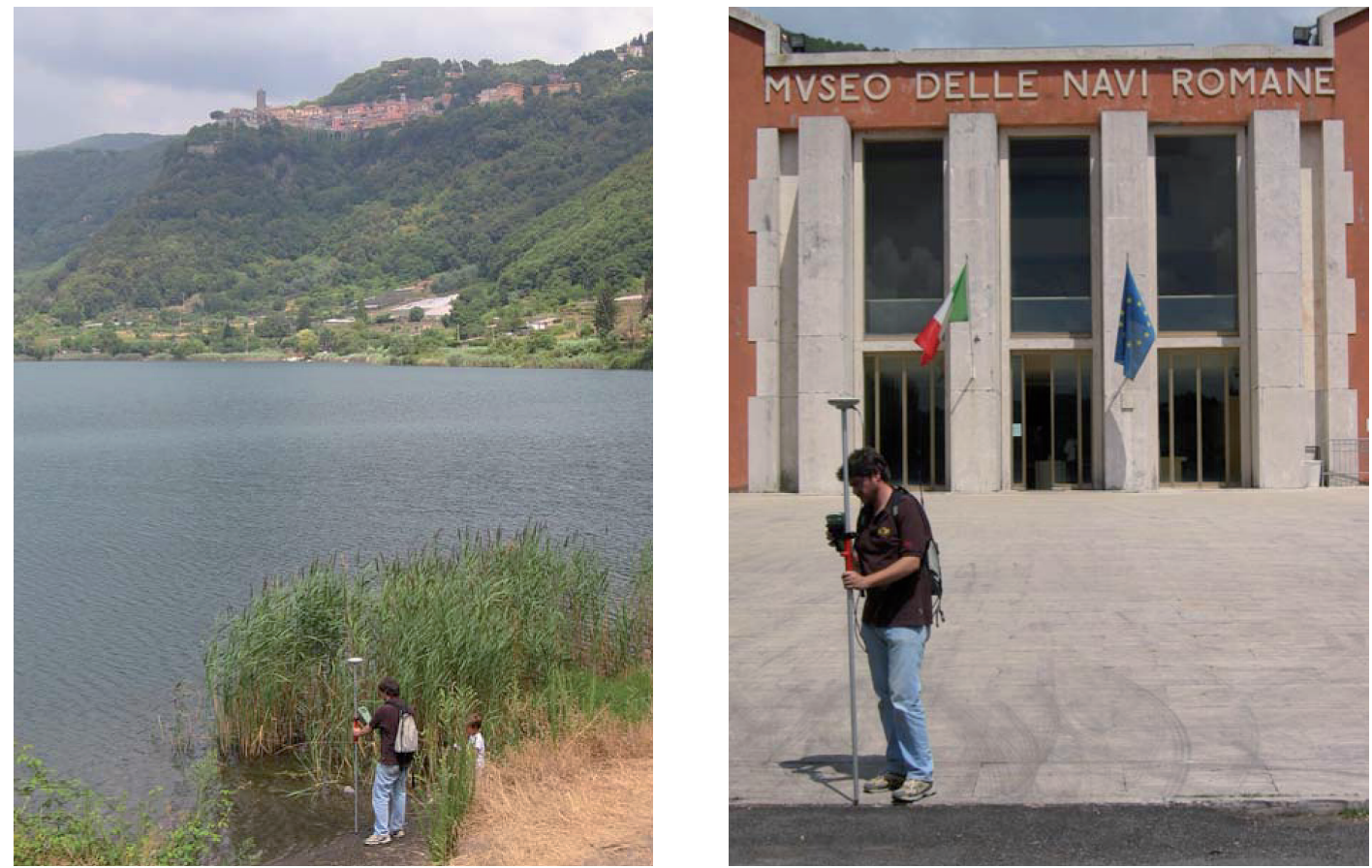

Fig. 4. GPS RTK survey to measure the lake levels: a) Nemi shoreline (1, fig. 1), b) the Roman ship museum near the Nemi lake (4, fig. 1).

sites connecting the receiver by a GSM to the Internet site of the RESNAP-GPS, a regional network devoted to the real time positioning and navigation maintained by the University La Sapienza of Rome (Crespi et al., 2006). The server receives the request of differential corrections from the rover receiver, identifies its position and sends it to the appropriate differential corrections. Thereafter, the receiver is able to estimate its own position rapidly (or better the antenna position). The time spent from calling the network to get the position is about 2 minutes. All the information on the GPS RTK surveys in the Roman area by the RESNAPGPS network is available at http://w3.uniroma1.it/resnap-gps.

The sites selected for the GPS RTK survey are (fig. 1):

1) the Albano shoreline, water level

2) the Nemi drainage tunnel

3) the Nemi shoreline, water level (fig. 4a)
4) the Nemi Roman ship museum (fig. 4b)

5) leveling benchmark (IGM, route 24, s.s. Appia).

All the heights obtained after the surveys refer to the WGS84 ellipsoid (table II) and are characterized by a mean precision within $5 \mathrm{~cm}$. To obtain the orthometric heights (asl) it is essential to know the geoid undulations. In this area the geoid is always above the reference ellipsoid by about $48 \mathrm{~m}$. The exact values of the geoidal undulations are estimated and validated by the International Geoid Service (Barzaghi et al., 2002) and provided to the users by IGM. The chosen geoid model is Italgeo99 with undulations given at 2' grid; the undulations corresponding to the surveyed sites come from interpolation (software Verto@ $\odot$ released by IGM). Table II shows the results obtained for the listed reference points, after the GPS RTK survey. The sites 2, 4 and 5 (table II, fig. 1) are three control sites for which we dispose the LIDAR 
Table II. GPS RTK survey, WGS84 coordinates, geoid undulations and orthometric heights.

\begin{tabular}{cccccccc}
\hline \hline site & \multicolumn{3}{c}{ GPS RTK WGS84 } & Italgeo99 geoid & GPS RTK & LIDAR & IGM leveling \\
\hline & Lat $(\mathrm{deg})$ & Long $(\mathrm{deg})$ & $\mathrm{h}_{\text {ell }}(\mathrm{m})$ & $\mathrm{N}(\mathrm{m})$ & $\mathrm{H}_{\text {orth }}(\mathrm{m})$ & $\mathrm{H}_{\text {orth }}(\mathrm{m})$ & $\mathrm{H}_{\text {orth }}(\mathrm{m})$ \\
\hline 1 & 414437.117 & 123918.488 & 336.60 & 48.447 & 288.16 & - & - \\
2 & 414243.500 & 124140.933 & 371.00 & 48.487 & 322.51 & 322.7 & - \\
3 & 414227.252 & 124227.581 & 367.51 & 48.487 & 319.02 & - & - \\
4 & 414317.456 & 124207.277 & 376.77 & 48.487 & 328.29 & 328.4 & - \\
5 & 414556.502 & 123704.116 & 231.92 & 48.390 & 183.53 & - & 183.576 \\
\hline
\end{tabular}

heights $(2,4)$ and the orthometric height from high precision levelling surveys (5). The control points show a very good agreement between the heights measured by different techniques, if the accuracy level of each single technique is taken into account. Comparing the LIDAR and RTK surveys, the differences are within $20 \mathrm{~cm}$, whereas differences between the RTK heights and the levelling heights, considered as a reference, are less than $5 \mathrm{~cm}$.

\section{Albano and Nemi morphometric updates and water volume changes}

The Colli Albani are composed of many different craters generated during the different eruptive phases of which the Albano and Nemi represent the more recent sites of activity; the Albano and Nemi lakes occupy the low part of these craters, their water surfaces and the circuit lengths are estimated at the time of the LIDAR survey; the water levels are achieved after the GPS RTK survey (July 2007), all reported in table III and table IV, units in meter above the mean sea level.

The orthometric height of the Albano and Nemi water levels are $288.16 \mathrm{~m}$ and $319.02 \mathrm{~m}$ (asl) respectively. The surface of the Nemi lake lies about $31 \mathrm{~m}$ above the Albano lake surface.

The main morphometric characteristics of the two craters sometimes differ from those reported by recent papers (Chondrogianni et al., 1996; Funiciello et al., 2003 and reference
Table III. Morphometric features of the lakes

\begin{tabular}{ccc}
\hline \hline & Albano & Nemi \\
\hline Area $(\mathrm{km} 2)$ & 5.79 & 1.72 \\
Circuit length $(\mathrm{km})$ & 9.5 & 5.4 \\
Low-rim height $(\mathrm{m})$ & 367.0 & 426.0 \\
Distance Lr-wl (m) & 78.8 & 107.0 \\
\hline
\end{tabular}

Table IV.Orthometric water heights (asl)

\begin{tabular}{ccc}
\hline \hline Lake level & Albano $(\mathrm{m})$ & Nemi $(\mathrm{m})$ \\
\hline GPS RTK & 288.16 & 319.02 \\
Bottom level & 121.8 & - \\
Water thickness & 166.36 & - \\
\hline
\end{tabular}

Table V. ellipsoidal water heights (WGS84)

\begin{tabular}{ccc}
\hline \hline Lake level & Albano (m) & Nemi (m) \\
\hline Bathymetry - Nov. 2005 & 336.7 & - \\
GPS RTK - Jul 2007 & 336.60 & 367.51 \\
\hline
\end{tabular}

therein). The Albano crater rim ranges between $367.0 \mathrm{~m}(\mathrm{NW})$ and about $530.0 \mathrm{~m}$ toward E-SE, where the slopes are steeper; the distance from 
Table VI. Water volume at different lake levels

\begin{tabular}{ccc}
\hline \hline Time (year) & h a.s.l. (m) & volume $(\mathrm{m} 3)$ \\
\hline 1993 & 293 & 472025901 \\
& 292 & 466115542 \\
& 291 & 460237073 \\
2007 & 290 & 454385524 \\
& 288.2 & 448566137 \\
& 288 & 442800840 \\
& 287 & 437097299 \\
& 286 & 431438370 \\
& 285 & 425825600 \\
span & 284 & 420255486 \\
2007-1993 & 283 & 414723105 \\
learly & 3.8 & 21710978 \\
& 0.27 & 1550784 \\
\hline
\end{tabular}

the water surface and the lowest rim is $78.8 \mathrm{~m}$. The Nemi crater rim ranges between $426.0 \mathrm{~m}$ (SW) and about $650.0 \mathrm{~m}(\mathrm{E})$ where is almost vertical, reaching about the slope of $83^{\circ}$ near the Nemi village; the distance from the water surface and the lowest part of the rim is $107.0 \mathrm{~m}$.

Table V shows the water levels in WGS84 ellipsoidal heights for the Albano lake from bathymetry (Anzidei et al., 2006) and for Albano and Nemi lakes from our GPS RTK survey.

The discrepancy between the Albano levels obtained from the bathymetric and the GPS RTK surveys may be explained taking into account the measurement uncertainties and the periodical variations due to seasonal influence.

It is worth noting that the water level of the Nemi lake is nowadays at $319.02 \mathrm{~m}$ (asl), about $3 \mathrm{~m}$ above the topographic height $(316 \mathrm{~m})$ reported on the IGM tables (Sheet 150, 1:25000), whereas the Albano water level is about $4.8 \mathrm{~m}$ below the topographic height $(293 \mathrm{~m})$ reported in the same table. These large differences are probably due to two different causes: at the time of the IGM survey (probably photogrammetric) the Nemi lake was recharging after the ships' recovery and it had not yet reached the equilibrium level, whereas the Albano lake underwent a more or less continuous lowering.

The hydrogeology of the Colli Albani area is interesting because different superimposed and isolated water tables are co-existing, due to the peculiar stratification of the volcano edifice (Bersani and Castellani, 2005); the main documented levels are the regional, the shallower perched and some different confined aquifers (Capelli and Mazza, 2005). The regional piezometric level is located topographically currently at $200 \mathrm{~m}$ (asl) and its drainage has a SW direction. The piezometric level of the perched aquifer crops out in the lakes of Nemi and Albano.

The Albano lake is now $166.36 \mathrm{~m}$ deep (with bottom at about $121.8 \mathrm{~m}$ (asl, table IV), thus intercepting both water flows and incurring in both level variations. In the last decade the water level progressively decreased. The main causes are still under debate but it seems that an important role is played by the increasing water extraction from various wells, variations of seasonal rainfall and deviations of water adductions for different aims (Capelli and Mazza, 2005).

For the first time, merging the information provided by the DTM and from the GPS RTK survey, it is possible to make a more detailed evaluation of the lake lowering, neglecting the discussion of its causes, and using the unified DTM (bathymetry and LIDAR) it is possible to infer the water volume change. To make such estimates we adopted the «cut and fill» procedure, an algorithm implemented in most of the software for DTM management. This procedure is often used in volumetric analysis based on DTMs, since it evaluates if the elevation of a surface has been modified by the removal or addition of surface material. In principle, this algorithm consists in calculating the differences between the heights derived from two different DTMs having the same grid or, in our case, be- 
tween the heights derived from the unified DTM and the reference heights reported in table VI. Assuming a constant height inside each cell, the averaged value of 4 heights pertaining to each cell, the volume change is obtained as the sum of products of the height difference by the area of each cell.

At the beginning we evaluated the change in lake volumes at different water levels: this information, even if approximate, can give some useful indications for researchers in different fields. We started to compute the volumes from heights near to the drain-tunnel, reported as 292 $\mathrm{m}$ asl (Ministero dei Lavori Pubblici, 1978) and proceeded with decreasing heights, including the value of $288.16 \mathrm{~m}$, the present water level estimated by the GPS RTK survey in July 2007 (table VI).

We take into account that in 1993 the lake was more or less at the level of the drain tunnel (Tanga et al. 1996) and then decreased without reaching this level any longer. If we hypothesize a linear trend with constant volume decreasing in these years, it is possible to estimate the annual loss of water volume from 1993 to 2007 in about $1550784 \mathrm{~m}^{3}$ (table VI). Table VI also reports the total amounts of water level decreasing from 1993 to $2007,3.8 \mathrm{~m}$, and the average loss level rate, about $27 \mathrm{~cm} / \mathrm{yr}$. Note that it is possible to retrieve a similar average value from fig. 6 of Capelli and Mazza (2005), the slope of the trend being about $22 \mathrm{~cm} / \mathrm{yr}$.

Supposing also that the volume trend will remain constant in the future, we can infer that in about 310 years the emptying of the Albano lake could be completed.

It is important to underline that these estimates have merely the value of approximate projections, since it is hard to predict the trend of the lake level in the coming years, the amounts of each different cause contributing to the drawdown being not completely predictable. Moreover we hope that the provisions applied by the authorities devoted to the environmental control of this beautiful area can limit the water table loss.

In opposition to the Albano lake lowering, the Nemi lake level is increased of about $3 \mathrm{~m}$, as reported in the previous section. Although the bottom of the Nemi lake is located at about the surface level of the Albano lake, this could be indirect proof that the two lakes belong to two different aquifers.

\section{Acknowledgements}

Research supported by the Dept. of Civil Protection, Project DPC115_V3 Colli Albani, RU.8 coordinated by F. Riguzzi. The suggestions given by P. Baldi were very useful to improve the manuscript. We are grateful to all the persons and researchers involved in this project; special thanks are due to Simone Atzori (INGV) and Loredana Liso (Provincia di Roma). We wish to acknowledge Mattia Crespi and the Leica Geosystems S.p.A. since part of this work is based on the RESNAP-GPS network

\section{REFERENCES}

Amato, A., C. Chiarabba., M. Cocco, M. Di Bona and G. SelvaGgi (1994): The 1989-1990 seismic swarm in the Alban Hills volcanic area, central Italy, J. Volcanol. Geotherm. Res., 61, 225-237.

Amato, A. and C. ChiarabBa (1995): Recent uplift of the Alban Hills volcano (Italy), evidence for magmatic inflation?, Geophys. Res. Lett., 22, 1985-1988.

Anzidei, M., P. Baldi, G. Casula, A. Galvani, F. Riguzzi and A. ZANUTTA (1998): Evidence of active crustal deformation of the Colli Albani volcanic area (central Italy) by GPS surveys, J. Volcanol. Geotherm. Res., 80, 55-65.

AnZIDEI, M., A. Esposito and F. DE Giosa (2006): The dark side of the Albano crater lake, Annals of Geophysics, 49 (6), 1275-1287.

Anzidei, M., M. L. Carapezza, A. Esposito, G. Giordano, M. LELLI and L. TARCHINI (2008): The Albano maar lake high resolution bathymetry and dissolved $\mathrm{CO}_{2}$ budget (Colli Albani volcano, Italy): Constraints to hazard evaluation, J. Volc. Geoth. Res., 171, 258-268.

Barzaghi, R., B. Betti, A. Borghi, G. SonA and V. TorNATORE (2002): The italian quasi-geoid, Bollettino di Geodesia e Scienze Affini, 1, 61, (1), 33-51.

Bersani, P. and V. CAstellani (2005):Considerations on water flow regulation in ancient time in the Alban Hills, Geologia Tecnica e Ambientale, 1, 59-102.

Boni, C., P. Bono, S. Lombardi, L. Mastrorillo and C. PerCOLO (1995): Hydrogeology, fluid chemistry, and thermalism, in The volcano of the Alban Hills, edited by RafFAello Trigila, (University of Rome «La Sapienza»), pp. 221-240.

Calcara, M., S. Lombardi and F. Quattrocchi, (1995): Geochemical monitoring for seismic surveillance, in The volcano of the Alban Hills, edited by RAFFAELLO Trigila, (University of Rome «La Sapienza»), pp. 243263. 
Capelli, G. and R. Mazza (2005): Water criticality in the Colli Albani (Rome, Italy), Giornale di Geologia Applicata, 1, 261-271, doi: 10.1474/GGA.2005-01.026.0026.

Capelli, G., R. Mazza, G. Giordano, A. Cecili, D. De RiTA and R. SAlvati (2000): The Colli Albani volcano (Rome, Italy): equilibrium breakdown of a hydrogeological unit as a result of unplanned and uncontrolled over-exploitation, Hydrogéologie, 4, 63-70.

Carapezza, M.L., B. Badalamenti, L. Cavarra and A. SCALzo (2003): Gas hazard assessment in a densely inhabited area of Colli Albani Volcano (Cava dei Selci, Roma), J. Volcanol. Geotherm. Res., 123, 81-94.

Carapezza, M.L., F. Barberi, L. Tarchini, L. Cavarra and D. GRANIERI, (2005): Le emissioni gassose dell'area vulcanica dei Colli Albani, in Nuovi dati sull'attività recente del cratere del Lago Albano e sul degassamento dei Colli Albani, edited by CARAPEZZA, M.L., et al. (Atti Acc. Naz. Lincei, vol. 218), pp. 229-242.

CARAPEZZA, M.L. and L. TARCHINI (2007): Accidental gas emission from shallow pressurized aquifers at Alban Hills volcano (Rome, Italy): Geochemical evidence of magmatic degassing?, J. Volcanol. Geotherm. Res., 165, 5-16.

Chiodini, G. and F. Frondini (2001): Carbon dioxide degassing from the Albani Hills volcanic region, Central Italy, Chem. Geol., 177, 67-83.

Chondrogianni, C., D. Ariztegui, P. Guilizzoni and A. LAMI (1996): Lakes Albano and Nemi (central Italy): an overview, Palaeoenvironmental Analysis of Italian Crater Lake and Adriatic Sediments, P. GuILIzZONI and F. OldFIELD (Guest Editors), Mem. Ist. Ital. Idrobiol., 55, 17-22.

Crespi, M., L. De Vendictis, U. Fabiani, L. Luzietti, A. MAZzONi and G. ReinA (2006): Applicazioni nel campo di posizionamento di precisione in tempo reale supportato da una rete di stazioni permanenti GNSS: RESNAP-GPS e l'esperienza nel Lazio, Atti della $X$ Conferenza Nazionale dell'ASITA, (Bolzano, 14-17 Nov. 2006, in Italian).

De Rita, D., R. Funiciello and M. Parlotto (1988): Geological Map of the Alban Hills Volcanic Complex, (CNR, Rome).

Devoti, R., F. Riguzzi, M. Cuffaro and C. Doglioni (2008): New GPS constraints on the kinematics of the Apennine subduction, Earth Planet. Sci. Lett., 273, 163-174.

Dragoni, W. (1998): Some considerations on climatic changes, water resources and water needs in the Italian region south of the $43^{\circ} \mathrm{N}$, in Water, Environment and Society in Times of Climatic Change, edited by N. BROWN and A.S. IsSAR A.S. (Kluwer Academic Publ. Netherlands), pp. 241-271.

Feuillet, N., C. Nostro, C. Chiarabba and M. Cocco (2004): Coupling between earthquake swarms and volcanic unrest at the Alban Hills Volcano (central Italy) modeled through elastic stress transfer, J. Geophys. Res., 109, B02308, doi: 10.1029/2003JB002419.

Freda, C., M. Gaeta, D.B. Karner, F. Marra, P.R.
Renne, J. Taddeucci, P. Scarlato, J.N., Christensen, and L. DALlai (2006): Eruptive history and petrologic evolution of the Albano multiple maar (Alban Hills, Central Italy), Bull. Volc,, 68, 567-591, doi: 10.1007/s00445-005-0033-6.

Funiciello R., G. Giordano, D. De Rita, M. L. CarapezZA and F. BARBERI (2002): L'attività recente del cratere del Lago Albano di Castelgandolfo, Rendiconti Lincei Scienze Fisiche e Naturali, Serie 9, 13 (3).

Funiciello, R., G. Giordano and D. De Rita (2003): .The Albano maar lake (Colli Albani Volcano, Italy): recent volcanic activity and evidence of pre-Roman Age catastrophi lahar events, J. Volcanol. Geotherm. Res., 123 (1), 43-61.

Ministero DeI LAVORI PubBlici (1978): Italian Government, 1978, Annali idrologici, (Servizio Idrografico, Ufficio Idrografico di Roma).

Mazzanti, P., F. Bozzano and C. Esposito (2007): Submerged landslide morphologies in the Albano Lake (Rome, Italy), Third International Conference on Submarine Mass Movement and their consequence, (Santorini 1-4 Ottobre).

Molin, D.,(1981): Sulla sismicità storica dei Colli Albani, (CNEN-RT/AMB (81), 11, Roma, 1-17).

Pietrantonio, G., V. Baiocchi, U. Fabiani, A. Mazzoni and F. RiguZZI (2008): Morphological updating on the basis of integrated DTMs: study on the Albano and Nemi craters, J. of Applied Geodesy, 2, 239-250, doi:10.515(JAG.2008.027.

Pizzino, L, G. Galli, C. Mancini, F. Quattrocchi and P. ScArlato (2002): Natural gas hazard $\left(\mathrm{CO}_{2},{ }^{222} \mathrm{Rn}\right)$ within a quiescent volcanic region and its relations with tectonic; the case of the Ciampino-Marino area, Alban Hills Volcano, Italy, Natural Hazards, 27 (3), 257-287.

Riguzzi, F. and A. Tertulliani (1988): I terremoti dei Castelli Romani dell'11 aprile 1987, Geologia Tecnica, 2, 38-43, (in Italian).

Salvi, S., S. Atzori, C. Tolomei, J. Allievi, A. Ferretti, F. Rocca, C. Prati, S. Stramondo and N. Feuillet (2004): Inflation rate of the Colli Albani volcanic complex retrieved by the permanent scatterers SAR interferometry technique, Geophys. Res. Lett., 31, 12.

TANGA, E., E. Liso and E. LuCANI (1996): Indagine sull'abbassamento del livello idrico dei laghi Albano e Nemi, Proceedings of Convegno sull'abbassamento dei laghi Albani, (Roma, Palazzo Valentini).

Tertulliani A. and F. RiguZZI (1995): Earthquakes in Rome during the past one hundred years, Annals of Geophysics, XXXVIII (5-6), 581-590.

Trigila R. (Editor) (1995): The volcano of the Alban Hills, (Tipografia SGS, Rome).

Tuccimei P., G. Giordano and M. Tedeschi (2006): $\mathrm{CO}_{2}$ release variations during the last 2000 years at the Colli Albani volcano (Roma, Italy) from speleothems studies, Earth Planet. Sci. Lett., 243, 449-462.

(received March, 21, 2008; accepted April 28, 2008) 